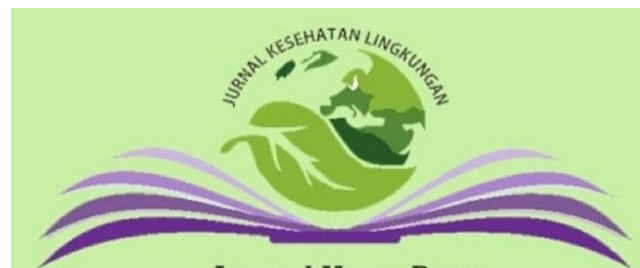

Journal Home Page:

https://e-journal.unair.ac.id/JKL

\section{Jurnal Kesehatan Lingkungan}

Vol. 14 No. 1

DOI: $10.20473 / j$ lkl.vl4il.2022.21-26

ISSN: 1829 - 7285

E-ISSN: 2040 - 881X

\title{
URINARY CADMIUM LEVEL CAUSING IMPAIRED KIDNEY FUNCTION IN FARMERS IN GINTUNGAN VILLAGE, BANDUNGAN DISTRICT
}

\section{Poppi Nastasia Yunita Dewi ${ }^{1 *}$, Nurjazuli Nurjazuli $^{1}$, Budiyono Budiyono ${ }^{1}$ \\ ${ }^{1}$ Master of Environmental Health, Faculty of Public Health, Universitas Diponegoro, Semarang 50275, Indonesia}

Corresponding Author:

*)poppi.nastasia@gmail.com

\section{Article Info}

Submitted :26 October 2021

In reviewed

Accepted

Available Online

17 November 2021

13 December 2021

31 January 2022

Keywords : Cadmium, Urine, Kidney, Protein, Farmers

Published by Fakultas Kesehatan Masyarakat Universitas Airlangga

\begin{abstract}
Introduction: Farmers apply pesticides to control pests on vegetable farming in Semarang regency. One of the active ingredients of pesticides is cadmium $(\mathrm{Cd})$, and exposure to cadmium in humans can interfere with kidney function. High exposure to $C d$ may cause the effects of chronic kidney failure. If there are a lot of free $C d$ ions in the body, the ability of the kidneys to produce metallothionein will be reduced. Thus, it may damage the kidney tubules as it results in high levels of urinary $C d$ which can be toxic. This study aimed to analyze an association between the levels of urinary $C d$ and impaired kidney function in farmers. Methods: This study was analytic observational and used designa cross-sectional study design. The population in this study was all farmers as many as 406 people in Gintungan village, Bandungan district, Semarang regency. There were 60 people selected as samples through purposive sampling. Results and Discussion: The level of urinary Cd in farmers on average was $0.958 \mu \mathrm{g} / \mathrm{L}$ with a standard deviation of $0.570 \mu \mathrm{g} / \mathrm{L}$. The highest level of $C d$ was $5.390 \mu \mathrm{g} / \mathrm{L}$ and the lowest was $<0.100 \mu \mathrm{g} / \mathrm{L}$. The results of the statistical chi-square test showed there was an association between levels of urinary $C d$ and impaired kidney function $(p=0.041)$. Conclusion: Impaired kidney function in farmers in Gintungan might be caused by the level of urinary $C d$. Further research should measure creatinine in the blood to ensure a decrease in the glomerular filtration rate in the kidneys of the farmers.
\end{abstract}

\section{INTRODUCTION}

Central Java province has a great potential of agriculture in the food sector. Bandungan district in Semarang regency is one of the largest producing areas of various plantations such as chili, mustard greens, leeks, cabbage, carrots, and tomatoes. Gintungan village is one of the largest crops producers. A common problem in the agricultural sector is damage on crops by nuisance organisms and pests. Farmers in Bandungan district often use insecticides and fungicides which are organophosphate to avoid the damage.

Excessive and uncontrolled use of pesticides may harm plants, environment, and human health. The World Health Organization (WHO) estimated around 1-5 million pesticide poisoning cases in farmers. The number of deaths is 220,000 every year, and $80 \%$ of poisonings occur in developing countries.

The use of pesticides and inorganic phosphate fertilizers can be an indicator of risk to farmers as they contain heavy metal cadmium (Cd) (1). The Cd content in this pesticide functions as the main component or complementary material used for adhesives (2). The pesticides and inorganic fertilizers, especially NPK fertilizers which contain nitrogen $(\mathrm{N})$, phosphate
$(\mathrm{P})$, and potassium $(\mathrm{K})$, consist of $85 \%$ to $90 \% \mathrm{Cd}$ in the manufacturing process. If the fertilizer is used excessively and sustainably over a long time, it can pose Cd contamination to humans and agricultural land (3).

In agricultural activities, the process of spraying pesticides likely spread $\mathrm{Cd}$ which then enters the body through the respiratory tract from air pollutants. It also can enter the body through the oral tract by consuming food contaminated with $\mathrm{Cd}$. It can only be absorbed into the human body about $5-10 \%$ and then excreted through the urine. Farmers are workers at risk of exposure to $\mathrm{Cd}$ since they use pesticides in daily work. Previous research conducted in Baturaden on ornamental plant farmers has shown that the urinary $\mathrm{Cd}$ content exceeded the normal threshold value (>2 $\mu \mathrm{g} / \mathrm{L}$ ), followed by a decrease in the glomerulus filtration rate (LPG). It indicates that exposure to $\mathrm{Cd}$ likely causes kidney problems.

Cd heavy metal has a high level of toxicity because of its widespread distribution and a biological half-life for 10-30 years in the body of living organisms. $\mathrm{Cd}$ also has non-degradable properties, and acute or chronic exposure to $\mathrm{Cd}$ will be vulnerable to human health, especially the kidneys prone to Cd effects (4). Cd absorbed into the body will combine with metallothionein 
protein and become a $\mathrm{Cd}+\mathrm{MT}$ bond which will form MT-1 protein settled in the kidneys. Cd bonds with metallothionein have stable properties which can trigger an increase or induce the formation of free radicals. The free radicals can cause lipid peroxidation that injures the kidneys as urinary creatinine and proteinuria or $\beta 2$ microglobulins increase (5).

Hepatotoxic effects, chronic renal failure, complications of diabetes, changes in bone structure, and blood pressure occur due to high levels of exposure. If the body contains a lot of free Cd ions, the kidney's ability to produce metallothionein will decrease. As a result, it likely damages the kidney tubules and results in high levels of urinary $\mathrm{Cd}$ which are toxic (6). The high toxic effect on the kidney causes degeneration of the renal tubular cells. Damage on the kidneys can be detected from the increased amount of urinary protein content. Proteins i.e., albumins and globulins are usually found in the urine (7).

Several previous studies have shown an association between impaired kidney function and agricultural activities, especially most of land activities which use chemicals intensively. Agrochemicals of which there are currently more than thousands active compounds such as agricultural chemicals, pesticides, and fertilizers are known to harm human health. Previous research conducted in Sri Lanka in 2017 has found an association between exposure to pesticide and chronic kidney disease unknown (CKDu) (8).

Impaired kidney function is a progressive condition characterized by the gradual loss of kidney function. The results of the Basic Health Research (Riskesdas) in 2018 showed that the percentage of people in Indonesia who had chronic kidney disease was $3.8 \%$ (9). In 2017, there were 30,831 new hemodialysis patients in Indonesia, of which $48.3 \%$ were associated with hypertension or diabetes and $4 \%$ associated with unknown chronic kidney disease (CKDu). Data on the number of hemodialysis patients in 2019 at the Ungaran Hospital, Semarang Regency showed each patient of 45 patients had a different frequency of therapy (10). Based on the interview results in Gintungan village, Bandungan district, Semarang regency, a female horticultural farmer suffered from kidney failure.

The preliminary interview results showed of three urine samples from a farmer group in Gintungan village, Bandungan district, one sample had urinary protein ( $>30 \mathrm{mg} / \mathrm{dL}$ ) exceeding the normal limit at 0-20 $\mathrm{mg} / \mathrm{dL}$. Impaired kidney function could be due to high urinary protein content. The interviews with the farmers showed that the a chemical pesticides was mixed with several heavy metals such as $\mathrm{Cu}, \mathrm{Cd}$, and $\mathrm{Mg}$ to make the leaves of the plants stronger.

The data accord with the results of preliminary research in agricultural environmental research center, which showed the area around agricultural land contained heavy metal in pesticide residues. Cd level in the land was $0.0457 \mathrm{mg} / \mathrm{L}$. In the soil, the Cd level was $1.87 \mathrm{mg} /$ $\mathrm{kg}$, and the water contained $\mathrm{Cd}$ of $<0.0027 \mathrm{mg} / \mathrm{L}$.

Few studies are conducted to identify the health effects of $\mathrm{Cd}$ pollution, the exposure to $\mathrm{Cd}$ may generate nephrotoxic substances that damage the kidneys. The purpose of this study was to analyze whether or not there is an association between levels of urinary $\mathrm{Cd}$ and impaired kidney function in farmers.

\section{METHODS}

This study was analytic observational and used a cross-sectional approach. It was conducted by measuring factors and effects at the same time. Observations, interviews, and sample measurements on respondents were taken to collect primary data. This study also involved statistical analysis to prove the relationship between an independent variable and a dependent variable.

This study was conducted in July-August 2021 in Gintungan village, Bandungan district, Semarang regency. The research population was all farmers amounting to 406 people in Gintungan village, Bandungan district. The sample size calculated using the Slovin formula obtained 40 samples. They were selected through purposive sampling according to the exclusion and inclusion criteria. The inclusion criteria for the respondents were farmers living in Gintungan village, Bandungan district for more than five years and those using chemical pesticides. Farmers in Gintungan village, Bandungan district who used organic pesticides were excluded from the selection.

The independent variable in this study was the level of urinary $\mathrm{Cd}$ as measured by the Atomic Absorption Spectroscopy (AAS) in environmental health and disease control laboratory, Yogyakarta, while the dependent variable was impaired kidney function measured from urinary protein levels using urinalysis reagent strips. Urine sampling was collected from early morning urine with a minimum volume of $20 \mathrm{ml}$, and the samples were then put into a urine container.

Bivariate analysis in this study was conducted to examine whether or not there is a relationship between levels of urinary $\mathrm{Cd}$ and impaired kidney function. The chi-square test was performed because the types of data for both variables were categorical data. This study 
has passed the ethical clearance from the Research Ethics Committee of the Faculty of Public Health, Diponegoro University, Semarang with No. 259/EA/ KEPK-FKM/2021.

\section{RESULTS}

The majority of the respondents in this study were males $(92.5 \%)$ at the average age range between 31-40 years. Of 40 respondents, there were 29 people (72.5\%) who had a smoking habit and 11 people $(27.5 \%)$ who did not have a smoking habit as evidenced by no consumed sticks. According to WHO, most of the respondents were 17 people (42.5\%) who were light smokers. Ten people $(25.0 \%)$ were moderate smokers, and two people were heavy smokers (5.0\%). Fourteen people $(35.0 \%)$ insufficiently drank water $(<2$ liters per day), and one person (2.5\%) had a history of diabetes. Most of the respondents (87.5\%) had a working mass of $>5$ years (Table 1 and Table 2).

Table 1. Selected Demographics, and Exposure Measures in Farmers $(n=40)$

\begin{tabular}{lc}
\hline Characteristics & N (\%) \\
\hline Male & $37(92.5)$ \\
\hline Age, years & $18(45.0)$ \\
$21-30$ & $20(50.0)$ \\
$31-40$ & $2(5.0)$ \\
$41-50$ & \\
\hline Education & $25(62.5)$ \\
$\quad$ Elementary school graduate & $12(30.0)$ \\
$\quad$ Middle school graduate & $2(5.0)$ \\
$\quad$ High school graduate & $1(2.5)$ \\
\hline Diabetes mellitus & $5(12.5)$ \\
\hline Consumption medicine & \\
\hline Smoking & $11(27.5)$ \\
$\quad$ Never & $17(42.5)$ \\
Light & $10(25.0)$ \\
$\quad$ Moderate & $2(5.0)$ \\
$\quad$ Heavy & \\
\hline Water consumption & $26(65.0)$ \\
$\quad$ Good & $14(35.0)$ \\
$\quad$ Insufficient & \\
\hline Working period & $5(12.5)$ \\
$\quad<5$ years & $35(87.5)$ \\
\hline 5 years &
\end{tabular}

Table 2. Health Outcome Measures in Farmers $(n=40)$

\begin{tabular}{lcccc}
\hline & Min & Max & Mean (SD) & Std. Deviation \\
\hline $\begin{array}{l}\text { Level of urinary } \\
\text { cadmium, } \mu \mathrm{g} / \mathrm{L}\end{array}$ & $<0.100$ & 5.390 & 0.958 & \pm 0.570 \\
$\begin{array}{l}\text { urinary protein, } \\
\mathrm{mg} / \mathrm{dL}\end{array}$ & 0 & 30 & 19.13 & \pm 12.704 \\
\hline
\end{tabular}

The examination of levels of urinary $\mathrm{Cd}$ in farmers was done using Graphite-AAS and compared with the Biological Exposure Index (BEI). Results showed that the average level of urinary $\mathrm{Cd}$ was $0.958 \mu \mathrm{g} / \mathrm{L}$ with a standard deviation of $\pm 0.570 \mu \mathrm{g} / \mathrm{L}$. The highest level of Cd was $5.390 \mu \mathrm{g} / \mathrm{L}$, and the lowest was $<0.100 \mu \mathrm{g} / \mathrm{L}$.
Meanwhile, urinary protein measurement showed that the highest urine protein was $30 \mathrm{mg} / \mathrm{dL}$, and the lowest was $0 \mathrm{mg} / \mathrm{dL}$ (Figure 1).

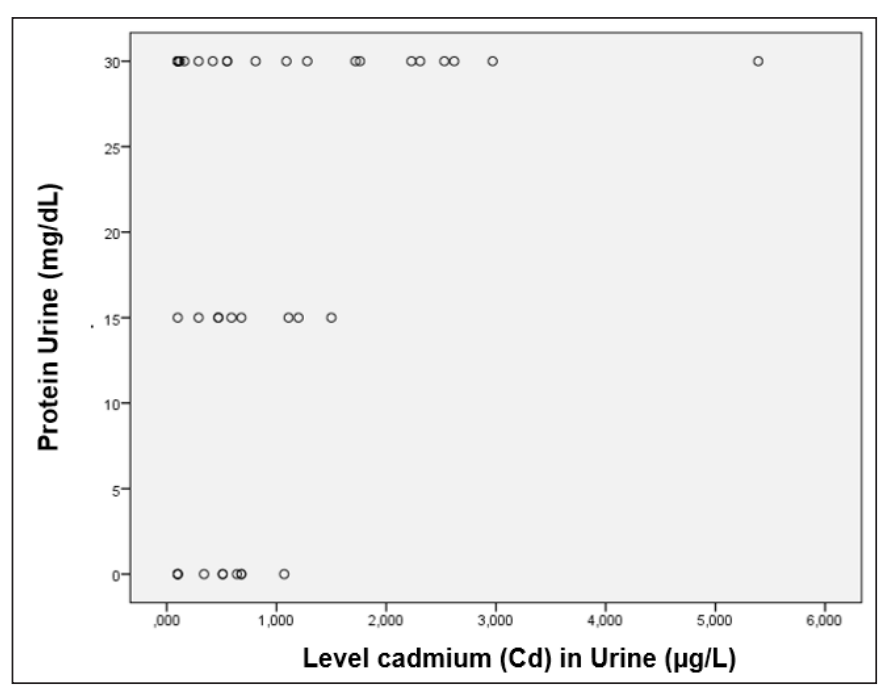

Figure 1. Plot of Added Variable in the Association Between Level of Urinary Cadmium (Cd) and Impaired Kidney Function

The results of the univariate analysis according to the Biological Exposure Index (BEI) in 2016 demonstrated the maximum limit of urinary $\mathrm{Cd}$ was 0.8 $\mu \mathrm{g} / \mathrm{L}(11)$. In other words, 25 people respondents $(62.5 \%)$ still meet the quality standard of the levels of urinary $\mathrm{Cd}$ $(<0.8 \mu \mathrm{g} / \mathrm{L})$. Meanwhile, 15 people (37.5\%) did not meet the quality standard of the levels of urinary $\mathrm{Cd}(>0.8 \mu \mathrm{g} /$ $\mathrm{L})$. The data on impaired kidney function were collected from the results of urinary protein levels in the farmers measured using urinalysis reagent strips. The testing results showed of 40 respondents, 21 people $(52.5 \%)$ had impaired kidney function, and 19 people $(47.5 \%)$ did not impair kidney function (Table 3 ).

Table 3. Frequency Distribution of Impaired Kidney Function and Levels of Urinary Cadmium (Cd) in Farmers

\begin{tabular}{lcc}
\hline & Frequency & $\begin{array}{c}\text { Percentage } \\
(\mathbf{\%})\end{array}$ \\
\hline Impaired kidney function & & \\
$\quad$ Yes (urinary protein of $>20 \mathrm{mg} / \mathrm{dL})$ & 21 & 52.5 \\
$\quad$ No (urinary protein of $0-20 \mathrm{mg} / \mathrm{dL})$ & 19 & 47.5 \\
\hline Level of urinary cadmium & & \\
$\quad$ Overqualified $(<0.8 \mu \mathrm{g} / \mathrm{L})$ & 25 & 62.5 \\
$\quad$ Not overqualified $(>0.8 \mu \mathrm{g} / \mathrm{L})$ & 15 & 37.5 \\
\hline
\end{tabular}

Ten poeple $(40.0 \%)$ who had levels of urinary Cd still met the quality standards and had impaired kidney function. Meanwhile, 11 respondents $(73.3 \%)$ who had levels of urinary $\mathrm{Cd}$ did not meet the quality standards and had impaired kidney function. The results of the chisquare test showed an association between levels of urinary $C d$ and impaired kidney function $(p=0.041)$ (see Table 4). 
Table 4. Analysis Results of the Association Between Levels of Urinary Cadmium (Cd) and Impaired Kidney Function in Farmers

\begin{tabular}{|c|c|c|c|c|c|c|c|}
\hline \multirow{3}{*}{$\begin{array}{c}\text { Level of } \\
\text { Urinary } \\
\text { Cadmium (Cd) }\end{array}$} & \multicolumn{4}{|c|}{$\begin{array}{c}\text { Impaired Kidney } \\
\text { Function }\end{array}$} & \multirow{2}{*}{\multicolumn{2}{|c|}{ Total }} & \multirow[t]{2}{*}{ P-Value } \\
\hline & \multicolumn{2}{|c|}{ Yes } & \multicolumn{2}{|c|}{ No } & & & \\
\hline & $\mathbf{N}$ & $\%$ & $\mathbf{N}$ & $\%$ & $\mathbf{N}$ & $\%$ & 00 \\
\hline Overqualified & 10 & 40.0 & 15 & 60.0 & 25 & 100.0 & 0.041 \\
\hline Not overqualified & 11 & 73.3 & 4 & 26.7 & 15 & 100.0 & \\
\hline
\end{tabular}

\section{DISCUSSION}

The urinary samples of farmers showed positive results of $\mathrm{Cd}$ content. Compared to the Biological Exposure Index $(\mathrm{BEI})$ regarding the maximum limit of urinary $\mathrm{Cd}$ content, 15 urine samples exceeded the standard quality. Indicated from the laboratory examinations, the average level of urinary $\mathrm{Cd}$ was 0.958 $\mu \mathrm{g} / \mathrm{L}$ with a standard deviation of $0.570 \mu \mathrm{g} / \mathrm{L}$. The highest level of $\mathrm{Cd}$ was $5.390 \mu \mathrm{g} / \mathrm{L}$, and the lowest was $<0.100$ $\mu \mathrm{g} / \mathrm{L}$.

These findings suggest the use of pesticides has contaminated the farmers, and their residues accumulated in the body. Pesticides used contain heavy metal $\mathrm{Cd}$ at $0.0457 \mathrm{mg} / \mathrm{L}$. The amount of accumulated pesticide that enters the body might be closely related to work period. The direct interviews with the respondents indicated that they had worked as farmers since $<15$ years old, and some even had worked as farmers for 35 years. Most of the farmers had a work period of $>$ 5 years. Longer work period might be the potential for bioaccumulation of pesticides in the body. They might use pesticides such as spraying pesticides in a longer period and thus get more risk of pesticide poisoning. This idea could be proven from increasing pesticide poison that is absorbed into the body and that impacts farmers health (12).

The high levels of urinary $\mathrm{Cd}$ occur because $\mathrm{Cd}$ is mostly excreted through urine, and only about $5-10 \%$ is absorbed into the body. Urinary Cd excreted exceeded the normal threshold and caused irritation of the respiratory tract, diarrhea, vomiting, and muscle contractions in the stomach (13). Most of the farmers got exposure to $\mathrm{Cd}$ in the workplace because of the use of pesticides and fertilizers, consumption of water and food, the use of tobacco, and air pollution. Cd enters the body through inhalation during the spraying process of pesticides which produces steam containing $\mathrm{Cd}^{2+}$ and $\mathrm{Cd}$ oxide (CdO). Exposure to $\mathrm{Cd}$ in smoke, vapors, and dust is about $10-50 \%$. If a person is exposed to steam containing Cd within 10 minutes at $190 \mathrm{mg} / \mathrm{m}^{3}$ or about $8 \mathrm{mg} / \mathrm{m}^{3}$ within 240 minutes (4 hours), it can cause a risk of death.
Twenty-one urine samples had abnormal protein content (> $20 \mathrm{mg} / \mathrm{dL}$ ). It indicated that 21 farmershad impaired kidney function. Knowing the urinary $\mathrm{Cd}$ level can detect impairment that occurs in the kidney organ system. The most effective biomarker to date for diagnosing chronic kidney disease and impaired kidney function is by checking urinary protein. Urinary protein is a condition of too much protein in the urine due to kidney damage (14).

The abnormal amount of urinary protein is an early sign of kidney disease. The mechanism of protein urination in the body occurs through macromolecules such as globulins and albumin that pass blood vessels and body tissues that act as a barrier. The inflammatory process in the glomerulus will have an impact on changes in the size of the barrier and disturbances in anionics, investing urinary protein. In the proximal convoluted tubule, microglobulins are filtered, absorbed, and catabolized in the glomerulus. Damage on the proximal tubular epithelium fails to absorb low protein molecular weight which is then excreted through the urine (15).

The damage on the kidneys' functional system can be caused by urinary Cd content (16). Abnormal levels of uric acid and phosphorus, as well as the levels of amniotic acid and glucosuria are indicators for kidney impairment because of exposure to metal $\mathrm{Cd}(17)$. When $\mathrm{Cd}$ enters the body, it will mostly settle in the kidneys, and it will be excreted through the gastrointestinal tract. In general, cadmium intoxication in humans, either acute or chronic, damages the respiratory system and kidney function. Urine is the fluid filtration residue in the glomerulus that is no longer needed in the body. Urine is processed in the kidneys and excreted from the body to canal. It contains $98 \%$ water and $2 \%$ nitrogen metabolism (urea, acid, uric, and creatinine). Some protein i.e., albumins and globulins is still frequently found in the urine (18).

This current study found an association between levels of urinary $\mathrm{Cd}$ and impaired kidney function in farmers. Direct observations of most of the farmers in Gintungan village showed they did not use complete personal protective equipment (PPE) when performing agricultural activities. For example, they did not use masks and gloves, and thus they were at more risk of exposure to $\mathrm{Cd}$ which can enter the body through inhalation, oral, or dermal contact (19). Cd is very easy to accumulate in the kidneys and liver, especially when it binds to metallothionein. Cadmium-metallothionein bonds in the kidney will pass the glomerulus and enter the proximal tubule (20). Cd in kidney cells will be excreted through urine. Cd has 10 to 30 years of the biologic half- 
life in the environment, while 7 to 30 years is its biologic half-life in the human body where it can penetrate the kidneys (21).

Since Cd levels are associated with impaired kidney function, it is a vital factor that damages the working system of the kidneys. In line with this finding, previous research of the National Health and Nutrition Examination Survey showed that if $\mathrm{Cd}$ level was at 0.41 $\mu \mathrm{g} / \mathrm{L}$, it could be a risk factor for chronic kidney failure. Damage on the structure of the nephron, especially in the proximal tubular epithelial cells, is caused by exposure to $\mathrm{Cd}$ (22). Hence, it can impair the renal function system followed by a reduction in the glomerular filtration rate. Substances e.g., urea in the metabolic wastes excreted by the kidneys will increase.

On the other hand, the disability to maintain homeostasis in the cells occurs due to high exposure to heavy metal cadmium, which eventually damages several types of cellular proteins and increases tissue apoptosis (23). One example of damage on the proximal renal tubule membrane is a decrease in fluidity caused by exposure to $\mathrm{Cd}$ because calcium and cadmium are antagonistic. These two substances may change calcium homeostasis and damage protein membrane (24). Impaired kidney function may reduce reabsorption of salt and water, and thus urine volume and the amount of urine protein (proteinuria) increase.

$\beta 2$ mikroglobulin, $N$-acetyl- $\beta-D$ glukosaminidase (NAG) and retinol binding protein which are proteinuria exist when low molecular protein increases. The continual exposure to $\mathrm{Cd}$ will cause tubular dysfunction and more acute glomerular damage. Thus, $\beta 2-\mathrm{M}$ levels will increase, and the glomerular filtration rate follows to decrease. The increase in proteinuria or $\beta 2-M$ levels in the farmers occurred due to daily exposure to $\mathrm{Cd}$. $\beta 2$ microglobulin as a polypeptide with a molecular weight of $11.8 \mathrm{kDa}$ is often found on the surface of nucleated cells in the human body. It is a component of the human leukocyte antigen (HLA) system which can be used as a benchmark for early detection of kidney function system diseases. The level of $\beta 2-\mathrm{M}$ or proteinuria will be higher if there is a reduction in the glomerular filtration rate (25).

When conditions are abnormal, the kidneys excrete urine from metabolism through protein (ureum). The urine could be too excessive in the body due to the high level of $\mathrm{Cd}$. As this substance is settled in the body, it migth intoxicate humans both physically and mentally.

Impaired kidney function could lead to metabolic disorders. Protein is one of the consitutens stored in the muscles (26). The metabolism of the muscle cells will produce creatinine, and the kidneys will excrete creatinine from the blood to the urine. When kidney function decreases, creatinine levels in the blood will increase.

Farmers need to prevent worse levels of $\mathrm{Cd}$ are by utilizing organic fertilizers and pesticides. The use of such organic products poses several benefits, for example, good quality crops and safe soil. It is also safer for people to consume vegetables with organic seed treatment as they might contain more nutritions.

\section{ACKNOWLEDGEMENTS}

The authors would like to express their gratitude to Mr. Nurjazuli and Mr. Budiyono who gave them guidance to work on the research. The authors also thanked to environmental health and disease control laboratory, Yogyakarta and all colleagues who helped collecting and examining the samples.

\section{CONCLUSION}

The average level of urinary Cd was $0.958 \mu \mathrm{g} / \mathrm{L}$ with a standard deviation of $0.570 \mu \mathrm{g} / \mathrm{L}$. The highest level of Cd was $5.390 \mu \mathrm{g} / \mathrm{L}$, and the lowest was $<0.100$ $\mu \mathrm{g} / \mathrm{L}$. This study showed an association between levels of urinary $\mathrm{Cd}$ and impaired kidney function in farmers in Gintungan village, Bandungan district ( $p=0.041$ ). This study recommends the farmers need to check and monitor their health and safety regularly as a form of early detection of kidney function impairment. Besides, farmers who spray pesticides must consider safe work procedures by optimizing the use of personal protective equipment to reduce the risk of exposure to pesticides. Those who got pesticide poisoning and high levels of urinary $\mathrm{Cd}$ and protein need to take a rest and further do immediate examination. Lastly, further research needs to investigate measure creatinine in the blood to ensure a decrase in the glomerular filtration rate the effect of exposure to pesticides in the kidneys of the farmers.

\section{REFERENCES}

1. Emurotu JE, Onianwa PC. Bioaccumulation of Heavy Metals in Soil and Selected Food Crops Cultivated in Kogi State, North Central Nigeria. Environ Syst Res. 2017;6(1):1-9. https://doi. org/10.1186/s40068-017-0098-1

2. European Parliament. The Use of Pesticides in Developing Countries and Their Impact on Health and The Right to Food. Belgia: Policy Department, Directorate General for External Policies; 2021. https://www.europarl.europa.eu/cmsdata/219887/ Pesticides\%20health\%20and\%20food.pdf

3. Bigalke $M$, Ulrich $A$, Rehmus $A$, Keller A. Accumulation of Cadmium and Uranium in Arable Soils in Switzerland. Environ Pollut. 2017;221(1):8593. https://doi.org/10.1016/j.envpol.2016.11.035

4. Rahimzadeh MR, Rahimzadeh MR, Kazemi S, 
MoghadamniaAA. Cadmium Toxicity and Treatment: An Update. Casp J Intern Med. 2017;8(3):135-145. https://doi.org/10.22088/cjim.8.3.135

5. Suhani I, Sahab S, Srivastava V, Singh RP. Impact of Cadmium Pollution on Food Safety and Human Health. Curr Opin Toxicol. 2021;27(1):1-7. https:// doi.org/10.1016/j.cotox.2021.04.004

6. Buha A, Dukic-Cosic D, Curcic M, et.al. Emerging Links Between Cadmium Exposure and Insulin Resistance: Human, Animal, and Cell Study Data. Multidisiplin Digit Publ Institue. 2020;8(63):1-16. https://doi.org/10.3390/toxics8030063

7. Lin $\mathrm{CT}$, Chen $\mathrm{TH}$, Yang $\mathrm{CC}$, Luo $\mathrm{KH}$, Chen $\mathrm{TH}$, Chuang HY. Epidermal Growth Factor Receptor (EGFR) Gene Polymorphism May be a Modifier for Cadmium Kidney Toxicity. Genes (Basel). 2021;12(10):1-10. $\quad$ https://doi.org/10.3390/ genes12101573

8. Valcke M, Levasseur ME, Soares Da Silva A, Wesseling C. Pesticide Exposures and Chronic Kidney Disease of Unknown Etiology: An Epidemiologic Review. Environ Heal A Glob Access Sci Source. 2017;16(49):1-20. https://doi. org/10.1186/s12940-017-0254-0

9. Ministry of Health of Republic Indonesia. Basic Health Research National Report. Jakarta: Health Research and Development Agency; 2018. https://www.litbang.kemkes.go.id/laporan-risetkesehatan-dasar-riskesdas/

10. Anggi N. Hubungan Lama Menjalani Hemodialisa dengan Tingkat Depresi pada Pasien Gagal Ginjal Kronik di RSUD Ungaran. Skripsi. Semarang: Universitas Ngudi Waluyo; 2020.

11. International Union of Pure and Applied Chemistry. Compendium of Chemical Terminology. Oxford: Blackwell Scientific Publications; 2020. https://doi. org/10.1351/goldbook.BT06901

12. Vutrianingsih NE, Zulfa I, Mukono J. Risk Factors Related to Karbamat Pesticide Poisoning and Organophosphate in Rice Farmers in Masangan Village Kulon Kabupaten Sidoarjo. Indones $J$ Public Heal. 2020;15(2):190-200. http://dx.doi. org/10.20473/ijph.v15i2.2020.190-200

13. Adhani R, Husaini. Logam Berat Sekitar Manusia. Banjarmasin: Lambung Mangkurat University Press; 2017.

14. Rachmadi D. Aspek Genetik Sindrom Nefrotik Resisten Steroid. Majalah Kedokteran Bandung. 2010;42(1):37-44. http://dx.doi.org/10.15395/mkb. $\mathrm{v} 42 \mathrm{n} 1.8$

15. Jumaydha LN, Assa YA, Mewo YM. Gambaran Kadar Protein dalam Urin pada Pekerja Bangunan. J e-Biomedik. 2016;4(2):1-5. http://dx.doi. org/10.35790/ebm.4.2.2016.14621

16. Yusuf $M$, Nurtjahja K, Lubis R. Analisis Kandungan Logam $\mathrm{Pb}, \mathrm{Cu}, \mathrm{Cd}$, dan $\mathrm{Zn}$ pada Sayuran Sawi,
Kangkung, dan Bayam di Areal Pertanian dan Industri Desa Paya Rumput Titipapan Medan. BioLink. 2016;3(1):56-64. https://doi.org/10.31289/ biolink.v3i1.812

17. Mayaserli DP, Rahayu JS. Perbandingan Kadar Logam Kadmium (Cd) dalam Urin Perokok Aktif dan Pasif di Terminal Kota Padang. Perintis's Heal J. 2018;5(1):58-64. https://doi.org/10.33653/jkp. v5i1.96

18. Surya AM, Pertiwi D, Masrul M. Hubungan Protein Urine dengan Laju Filtrasi Glomerulus pada Penderita Penyakit Ginjal Kronik Dewasa di RSUP Dr. M.Djamil Padang tahun 2015-2017. J Kesehat Andalas. 2018;7(4):469-474. http://doi. org/10.25077/jka.v7i4.903

19. Sofiana KD, Y.W. PM, Husnul K, Widodo MA. Analysis of Low-Level Cadmium Exposure Effects on HUVECs (Human Umbilical Vein Endothelial Cells) Cell Viability and Morphology. J Agromedicine and Med Sci. 2019;5(1):50-55. https://doi. org/10.19184/ams.v5i1.9126

20. Tsai TL, Kuo CC, Pan WH, Chung YT, Chen CY, Wu TN, et al. The Decline in Kidney Function with Chromium Exposure is Exacerbated with Co-exposure to Lead and Cadmium. Kidney Int. 2017;92(3):710-720. http://dx.doi.org/10.1016/j. kint.2017.03.013

21. Hernayanti H, Santoso S, Lestari S, Prayoga L, Kamsinah K, Rochmatino R. Efek Paparan Kadmium (Cd) terhadap Fungsi Ginjal Pekerja Bengkel Las. Kesmas Indones. 2019;11(1):1-8. https://doi.org/10.20884/1.ki.2019.11.1.1422

22. Sugiharto SB, Suwarso S, Prawirohardjono W. Level of Cadmium and Kidney Function Reviewed from Ureum Rate and Creatinine of Exhaust Welding Workers in Purbalingga. Public Med News. 2016;32(4):119-124. $\quad$ https://doi.org/10.22146/ bkm.7326

23. Berniyanti T. Biomarker Toksisitas: Paparan Logam Tingkat Molekuler. Surabaya: Airlangga University Press; 2018. https://repository.unair.ac.id/86164/1/ Biomarker Toksisitas HAKI.pdf

24. Nafiisah N, Laksana ASD, Mulyanto J. Correlations of Cadmium Exposure With the Ureum and Creatinine Serum Levels in Baturaden Ornamental Plant Farmers. Biomedika. 2020;12(2):79-84. https://doi.org/10.23917/biomedika.v12i2.10416

25. Rahmawati F. Laboratory Aspect of Chronic Kidney Disease. J IIm Kedokt Wijaya Kusuma. 2017;6(1):14-22. http://dx.doi.org/10.30742/jikw. $\underline{\mathrm{v} 6 \mathrm{i} 1.323}$

26. Ibrahim I, Suryani I, Ismail E. Hubungan Asupan Protein dengan Kadar Ureum dan Kreatinin pada Pasien Gagal Ginjal Kronik yang Sedang Menjalani Hemodialisa di Unit Hemodialisa RS PKU Muhammadiyah Yogyakarta. JNutr. 2017;19(1):1-6. https://doi.org/10.29238/jnutri.v19i1.34 